高温超電導応用機器の数值解析技術の現状

\author{
植田 浩史 ${ }^{* 1, \dagger}$ ，野口 聡*2，石山 敦士*3

\section{Current Status of Numerical Simulation Techniques for High-Temperature Superconducting Application Equipment}

\author{
Hiroshi UEDA $^{* 1, \uparrow}$, So NOGUCHI ${ }^{* 2}$ and Atsushi ISHIYAMA ${ }^{* 3}$
}

\begin{abstract}
Synopsis: High-temperature superconducting (HTS) wires such as those used for Bi-2223 and REBCO tapes, which are commercially available, are expected to be used in future electric power devices and high-field magnets because of their good criticalcurrent characteristics at high temperatures and in high applied magnetic fields. Therefore, the importance of numerical simulation techniques for HTS applications has increased. Recently, special sessions on numerical simulation of HTS modeling and applications have been held at academic conferences and workshops. Generally, the electromagnetic phenomena including HTS materials use the eddy current problem of Maxwell's equations together with nonlinear constitutive relationships between the electric field and current density. Until now, the user him/herself had to code a special program in order to manage the modeling of HTS materials and formulations of electromagnetic phenomena including HTS materials. However, recently, the numerical simulation on HTS applications using commercial software has been reported. In this paper, the current status of numerical simulation techniques for HTS applications is reviewed.
\end{abstract}

Keywords: HTS application, numerical simulation, optimization, superconducting property

(Some figures in this article may appear in color only in the electronic version)

\section{1.はじめに}

高温超電導線材の中でも，特に希土類系高温超電導 （REBCO）線材は，優れた機械特性と，高い磁場中臨界電 流密度を有することから, 超電導応用が開発当初から期待 され，現在は市販されるに至っている。また機械強度に課 題のあった Bi2223 線材も機械特性を向上した超高強度超 電導線 DI-BSCCO ${ }^{\circledR}$ Type HT-NX が販売されている。この ように高温超電導線材が市販・供給されるようになり，高

Received January 25, 2019

${ }^{* 1}$ 岡山大学 大学院自然科学研究科

干700-8530 岡山県岡山市北区津島中 3-1-1

Graduate School of Natural Science and Technology, Okayama

University, 3-1-1 Tsushima-naka, Kita-ku, Okayama 700-8530, Japan

*2 北海道大学 大学院情報科学研究科

干060-0814 北海道札幌市北区北 14 条西 9 丁目

Graduate School of Information Science and Technology,

Hokkaido University, Kita 14 Nishi 9, Kita-ku, Sapporo,

Hokkaido 060-0814, Japan

*3 早稲田大学 理工学術院

干169-8555 東京都新宿区大久保 3-4-1

Faculty of Science and Engineering, Waseda University, 3-4-1

Ohkubo, Shinjuku-ku, Tokyo 169-8555, Japan

† E-mail: hiroshi.ueda@okayama-u.ac.jp

DOI: $10.2221 /$ jcsj.54.89
温超電導応用の研究開発が進んでいく中で, 超電導体を含 む電磁場数值解析の重要性の認識が高まってきている。例 えば, 超電導応用に関する代表的な国際会議 ASC (Applied Superconductivity Conference), MT (International Conference on Magnet Technology), EUCAS (European Conference on Applied Superconductivity) においても, 高温超電導体を含 む数值解析に関する Special Session があり, 活発な議論が なされている。また, 超電導応用の数值解析に関する国際 ワークショップとして, CHATS on Applied Superconductivity や International Workshop on Numerical Modelling of High Temperature Superconductors が 1 年おきに交互に開催されて いる。後者は HTS Modelling Workgroup が運営している ワークショップである。このように現在多くの研究者に よって数值解析を利用した超電導機器の研究開発が進めら れるようになってきた。

一般に, 超電導応用機器の数值解析では, 超電導体内の 巨視的電磁現象は準定常状態の Maxwell 方程式から導出さ れる支配方程式を基に考える。したがって, 超電導応用機 器の設計などにおいて, 超電導の特徵を高電流密度が流せ る導線・コイルとして扱う程度であれば, 従来の電磁場解 析手法・商用ソフトで事足りる。しかし, 臨界電流, ピン 


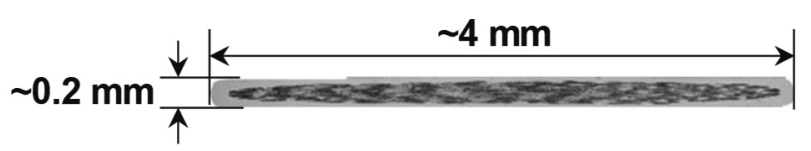

(a) Bi2223 (DI-BSCCO Type H) $)^{4}$

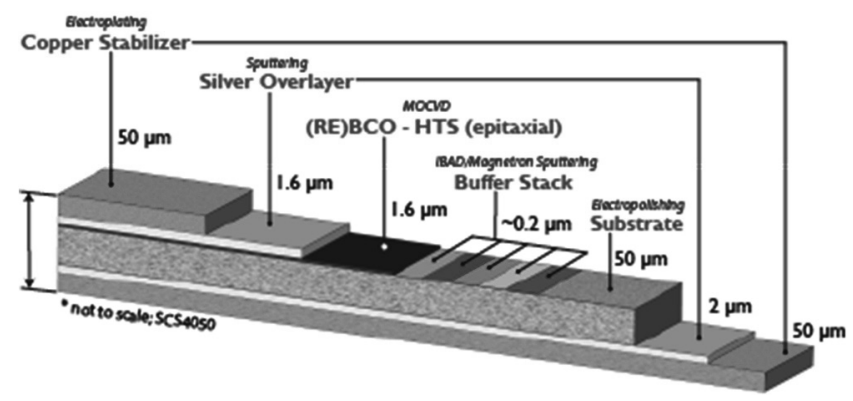

(b) $\mathrm{REBCO}^{5}$

Fig. 1 Structure of HTS tape.

ニング, 電流一電圧特性などの超電導特有の問題を考慮し ようとすれば，解析コードを自作するか，既存のソフトの カスタマイズが必要であった。また，温度や歪みによって も超電導特性が変化するため, 連成解析（マルチフィジッ クス解析）も場合によっては必要となる。これらが，これ まで超電導の数值解析の敷居が高くなっていた要因であろ う。一方で, 近年は商用ソフトでもマルチフィジックスが 扱えるようになり，偏微分方程式で記述される任意の物理 現象を扱うプラットフォームの実装も進みつつあり，それ らを利用した解析も見られるようになってきた。

筆者らは，2012～2013 年に「低温工学」の基礎講座と して 3 回にわたって「応用電磁気学 : 超電導機器応用のた めの電磁界数值解析」1-3)を連載した。今回の解説では, 基礎講座で触れられなかったことやその後の電磁場解析の トピックスを中心に高温超電導応用機器の数值解析の現状 について概説する。なお，本解説で紹介する内容は日本の 研究成果が多いが，高温超電導体を含む電磁場解析の分野 では日本の研究者が精力的に新しい手法やモデル化に取り 組んでいるためであることをご理解いただきたい。

\section{2. 高温超電導の数值解析手法}

高温超電導線材を利用した応用機器の解析の難しさは, 線材形状と超電導特性にある。これら高温超電導線材の多 くは Fig. 1 のようにアスペクト比が $10^{-3} \sim 10^{-4}$ と高いテー プ形状をしているため, 実用上は交流損失や遮蔽電流など の問題が発生し, 数值解析では精度よく計算することが難 しくなっている。一般に線材形状の問題は，定式化におい て, 薄膜近似を用いることで解決している。しかし，薄膜 近似により，膜厚方向の電磁場分布は無視されるため，そ の場合の影響について知っておくことは重要である。さら
に，薄膜近似と積分方程式を組み合わせる定式化では，積 分項の計算量が膨大になるため，解析時間も非常にかかる。 そこで, 積分項の計算に何らかの工夫を施す必要があり, ここでも何らかの近似計算が入ることになる。

\section{1 薄膜近似}

Bi2223 線材は多芯線テープ線, REBCO 線材は薄膜テー プ線である。超電導応用機器によって, 線材内の物理現象 の情報や解析精度がどこまで必要になるかを考えて線材の モデル化や支配方程式の定式化をしなければならない。

\section{（1）T法（積分方程式）}

一般に, REBCO 超電導層の厚さは $0.5 \sim 2.0 \mu \mathrm{m}$ 程度であ るため, 厚さ方向の電流を無視する薄膜近似を用いること が多い。この場合の電磁場解析は未知数を電流ベクトルポ

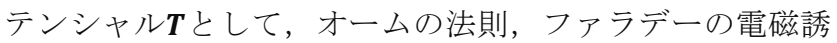
導の法則, ビオ・サバールの法則に薄膜近似を適用して導 かれた以下のような支配方程式をもとにする ${ }^{6-8)}$

$$
\begin{aligned}
& \{\boldsymbol{\nabla} \times \rho(\boldsymbol{\nabla} T \times \boldsymbol{n})\} \cdot \boldsymbol{n} \\
& +\frac{\mu_{0} d}{4 \pi} \frac{\partial}{\partial t} \int_{S} \frac{\left(\boldsymbol{\nabla} T^{\prime} \times \boldsymbol{n}^{\prime}\right) \times \boldsymbol{R}}{R^{3}} \cdot \boldsymbol{n} d S^{\prime}=-\frac{\partial \boldsymbol{B}_{0}}{\partial t} \cdot \boldsymbol{n}
\end{aligned}
$$

$T$ とT'はそれぞれ観測点とソース点におけるテープ面法 線方向の電流ベクトルポテンシャル成分, $\boldsymbol{n}$ と踩はそれぞ れ観測点とソース点のテープ面法線方向の単位ベクトルで ある。Rはソース点から観測点への方向ベクトル， $\boldsymbol{B}_{0}$ は外 部磁場， $\rho$ は超電導体の抵抗率， $\mu_{0}$ は真空中の透磁率， $d$ は超電導層の厚みである。積分範囲 $S$ は超電導テープ面の 全領域である。(1)式の積分項は, テープ間の磁気カップ リングを表わしており, 数值計算の際の離散化の結果, 密 行列になる。コイル巻線は薄い線材と絶縁材や含浸材の多 重積層構造になるため, この密行列のメモリ容量は膨大に なり, 解析時間も非常にかかる。そこで, 積分項の計算に 何らかの工夫を施す必要がある（後述 2. 3)。そのため, $\boldsymbol{T}$ 法の積分方程式を使った定式化はあくまで自作プログラム で行われることが多い。

\section{（2） $T-A$ 法 ( $H-A$ 法 $)$}

商用ソフトを利用した解析も行われ始めている。商用ソ フトでは, 静磁場解析, 渦電流解析, 非線形解析など解析 モデルや状況に応じて, 変数や手法を選択して数值解析が 行えるようになっている。物理現象の支配方程式は, ポア ソン方程式, 波動方程式, 拡散方程式に帰着されるため, 方程式の係数や境界条件を物理現象に合わせて正しく設定 できれば，数值解析のプロセスは 3 通りに集約されるはず である。この考えに基づいた計算パッケージ（例えば, COMSOL の PDE (Partial Differential Equation) パッケージ など）も用意されており，任意の物理現象の偏微分方程式 をユーザが正しく導ければ，それを基に数值解析を行える ようになっている。なお, HTS Modelling Workgroup のホー ムページ (http://www.htsmodelling.com/) では, フリーソフ トや商用ソフトを利用した計算例が紹介されているので, 


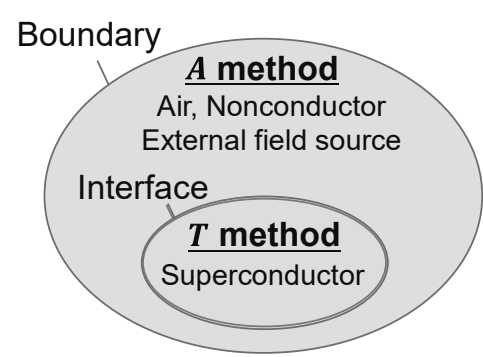

(a) Coupling problem

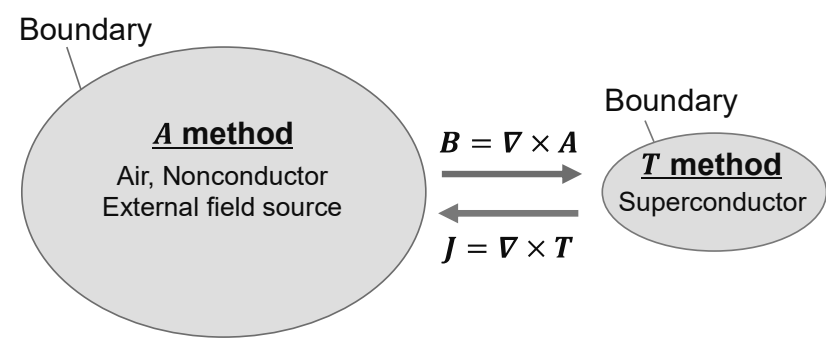

(b) Two variables are solved separately.

Fig. $2 \boldsymbol{T}-\boldsymbol{A}$ method. This figure is modified based on $\mathrm{H}$. Zhang et al. ${ }^{9)}$

興味がある方は参照されたい。

COMSOL の PDE（Partial Differential Equation）パッケー ジを利用した解析の例を示す。微分方程式から有限要素法 の定式化を利用するが, 磁気ベクトルポテンシャル $(\boldsymbol{A}$ 法 $)$ と電流ベクトルポテンシャル（T法）を併用する計算手法 がしばしばみられる。この方法では，超電導体（導体）を 含屯領域では, 次の 2 つの方程式

$$
\begin{aligned}
& \boldsymbol{J}=\boldsymbol{\nabla} \times \boldsymbol{T} \\
& \boldsymbol{\nabla} \times \boldsymbol{E}=-\frac{\partial \boldsymbol{B}}{\partial t}
\end{aligned}
$$

から，支配方程式は

$$
\boldsymbol{\nabla} \times \rho(\boldsymbol{\nabla} \times \boldsymbol{T})=-\frac{\partial \boldsymbol{B}}{\partial t}
$$

となる。一方, その他の解析領域では, 次の 2 つの方程式

$$
\begin{aligned}
& B=\nabla \times A \\
& \nabla \times H=J
\end{aligned}
$$

から，支配方程式は

$$
\boldsymbol{\nabla} \times \frac{1}{\mu}(\boldsymbol{\nabla} \times \boldsymbol{A})=\boldsymbol{J}
$$

となる。(4)(7)を解くには, 㛜密には, Fig. 2(a)のようにT法 の解析領域と電流分布を求め, 解析空間全体には $\boldsymbol{A}$ 法の解 析領域の境界で適切な接続条件を与えて, $\boldsymbol{T}$ 法と $\boldsymbol{A}$ 法の連成 問題を解かなければならない。しかし，H. Zhang らは，

Fig. 2(b) のように超電導体（導体）の領域にT法により電 流分布を, 解析空間全体では $\boldsymbol{A}$ 法により磁場分布を別々に 計算し, 磁束密度 $\boldsymbol{B}$, 電流密度 $\boldsymbol{J}$ を 2 つ領域でやり取りす る（式(4)(7)の右辺ソース項）ことを提案している。適用例 として, HTS 線材に薄板近似を用いて, パンケーキ巻の巻
線構造を考慮した解析結果を示している9)。また， R. Blambillia らは, 高温超電導回転機の 2 次元解析において, 解析領域をロータ（回転部）とステータ（静止部）に分け て，上記の手法を適用することを提案している ${ }^{10)}$ 。

\section{2 薄膜厚さの効果}

異常横磁場効果は, テープ面に垂直な方向の磁化を, テープ面に平行な方向に付加的に交流磁場を印加すること で, 緩和させるものである 11,12)。したがって，数值解析に 際しては, REBCO 層の厚さ方向の電磁場分布も考えけれ ばならず，薄膜近似が使えない。S. Noguchi らは，2 次元有 限要素法 $(\boldsymbol{A}-\boldsymbol{\phi}$ 法) を用いて, REBCO 線材断面を解析対 象に線材内電流分布の異常横磁場効果による変化を, 付加 的に印加される交流磁場のテープ面に対する角度を変えて 計算している ${ }^{13)}$ 。

\section{3 計算量削減（高速化）}

（1）高速計算手法 H. Ueda らは, 高速多重極法（Fast Multipole Method）を(1)の積分項に適用することでメモリの 容量の節約，計算の高速化を図っている ${ }^{8)}$ 。この手法を 10 $\mathrm{T}$ 級の冷凍機伝導冷却 REBCO コイルの発生磁場の計算に適 用した結果，実験と解析結果は非常に良く一致している ${ }^{14)}$

N. Tominaga らは積分項に階層型行列法 (Hierarchical matrices, H-matrices）を適用することで, メモリの容量の節 約, 計算の高速化が可能であることを示した ${ }^{15)}$ 。Y. Sogabe らはコサインシータ・ダイポールマグネットに対して, リ ターンヨークの部分に鏡像法を利用して, 解析領域の削減 を図っている ${ }^{16)}$

（2）巻線構造のモデル化 数值計算に際して, 巻線構 造を厳密にモデル化し, テープ間の磁気カップリングをす べて考慮しようとすると, メモリ容量は膨大になり, 解析 時間も非常にかかる。そこで，巻線構造のモデル化におい て何らかの近似を施すことも計算コストの削減になると考 えられる。

Y. Sogabe らは入れ子近似（Nested-loops approximation）お よびブロック近似（Block approximation）を併用して，鞍型

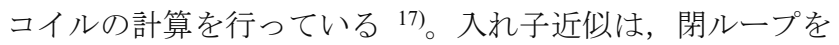
線材厚さ方向に重ね, 各ターンが回路的に並列接続された 状態とし, 全てのターンに同じ大きさの電流が流れている とする近似である。ブロック近似は隣接する複数のターン を一つのブロックとして扱い，そのブロックを代表する一 つのターンのみを解析対象とし, 同じブロックに属する代 表ターン以外は代表ターンと同様の電流分布となっている と仮定して解析を行う。E. Pardo は Continuous approximation を利用した計算結果を示している ${ }^{18)}$ 。解析対象をいくつか のセクターに分割し, 注目しているセクター内では巻線構 造を考慮した計算を行い，それ以外のセクターは均一電流 が流れているバルク導体と見做して計算する。セクター毎 に上記を計算を行い，収束するまで計算を繰り返す。この 手法は，セクター毎の計算で並列計算を用いることができ 


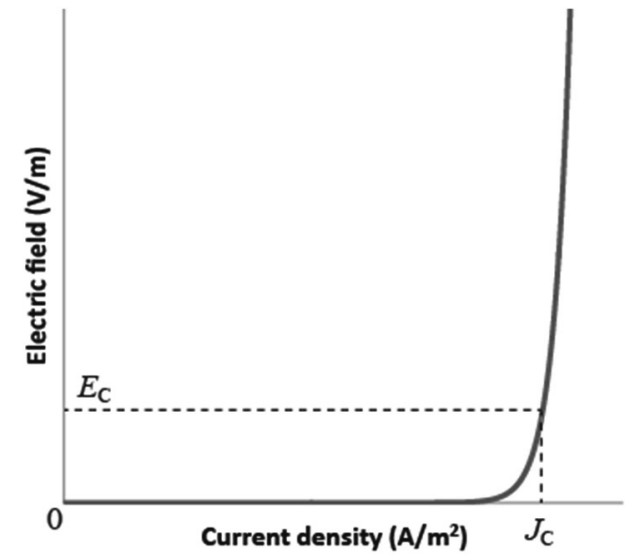

Fig. 3 Typical current transport property of HTS material. $J_{C}$ is critical current density and $E_{c}$ is the criterion of critical current density.

る。なお， E. Pardo は，上記計算に際して，一般に用いら れている有限要素法ではなく, Minimum Electro Magnetic Entropy Production (MEMEP) と呼ばれる変分原理に基づく手 法を使っている ${ }^{19)}$ 。

\section{3. 高温超電導体の超電導特性}

Maxwell の方程式を解くには，超電導体についての物 質方程式（構成方程式）が必要である。超電導体の電磁現 象を渦電流問題として考える場合，超電導体の特徴を表す 物質方程式は電界 $\boldsymbol{E}$ と電流密度 $\boldsymbol{J}$ との関係によって与えら れる。この方程式によって, 超電導体における基本的な特 性，すなわち電気抵抗がゼロの直流電流が流せることや変 動磁場下などにおける不可逆性が再現される。高温超電導 線材は, その臨界電流特性や電流一電圧特性が磁場に対し て異方性を持っており，また，人工ピンの導入などで角度 依存性が複雑になる。臨界電流の磁場強度・角度依存性を 実験結果にフィッティングさせる数式は例えば文献 14)20) に載っている。しかし, 磁場精度を要求されるような応用 では, 数值解析でどんなに精度を上げても, 結局, 臨界電 流特性の数值モデルの再現精度以上の精度は期待できない。 また，磁場の時間安定性を議論する場合などは，励磁後の 磁場の緩和特性は線材内の遮蔽電流分布が電流一電圧特性に 沿って，低電界側に緩和していく結果であるため，電流一電 圧特性そのものが重要となる。

一般に高温超電導体の電流一電圧特性は, Fig. 3 のよう に輸送電流を増加させていった場合にシャープな超電導一 常電導転移を示さず, 電流密度 $J$ が臨界電流密度 $J_{C}$ より小 さくても, 超電導体中に生じる電界 $E$ はゼロにならず, 徐々に抵抗が発生し電圧が上昇していく。このような超電 導体内の電磁現象（E-J特性）を記述するモデルとして は，べき乗則で近似したモデル（以下， $n$ 值モデルと呼ぶ） があり，次にように表される。

$$
E=E_{c}\left(\frac{J}{J_{c}}\right)^{n}
$$

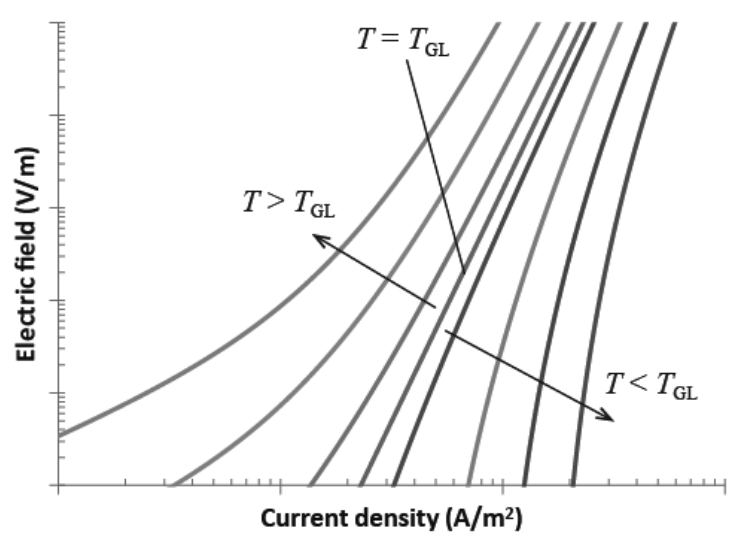

(a)

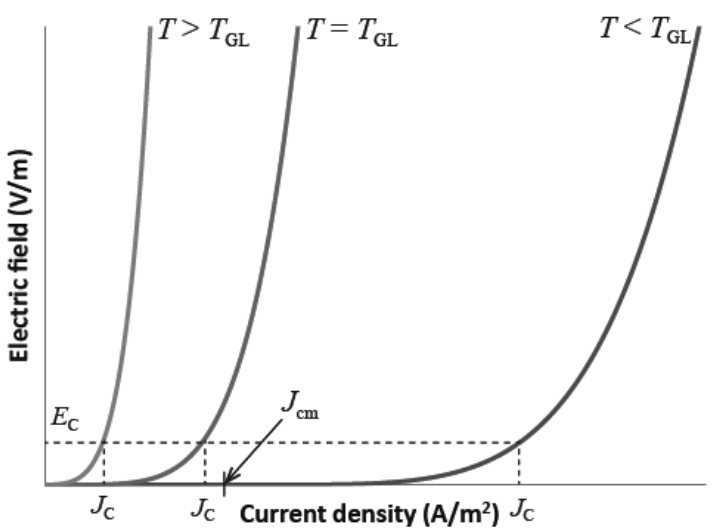

(b)

Fig. $4 E-J$ characteristics of the percolation model. (a) Double logarithmic plot. (b) Linear plot.

ここで， $E_{c}$ は超電導体の臨界電流密度 $J_{C}$ を定義する基準 值である。この基準值として例えば $1 \mu \mathrm{V} / \mathrm{cm}$ が用いられ る。上式中で与えられている指数 $n$ を $n$ 值と呼び, 高温超 電導体の非線形性を示すパラメータとして， $J_{c}$ とともに用 いられている。

しかし， $n$ 值モデルはある電界範囲に限られる。一般に は磁束フローが発生しているような高電界から臨界状態に 近い低電界の間で $n$ 值を一定として考えることはできず, $n$ 值は電界に依存して変化する。このような $E-J$ 特性を 両対数で描くと, Fig. 4(a)のように上に凸な曲線から下に 凸な曲線に変化することがわかる。このような広範囲にわ たる複雑な $E-J$ 特性を記述するためには, 式(8)において $n$ 值に電界依存性を持たせることも考えられるが，より正 確に記述するモデルとして磁束クリープ・フローモデル 21) やパーコレーションモデル ${ }^{21)}$ が提案されている。ここで は，磁束クリープを考慮していないパーコレーションモデ ルに基づく $E-J$ 構成関係を記すことにする。

$T \leq T_{G L}$ のとき,

$$
E=\frac{\rho_{F F}}{m+1} J\left(\frac{J}{J_{0}}\right)^{m}\left(1-\frac{J_{c m}}{J}\right)^{m+1}
$$

$T>T_{G L}$ のとき， 


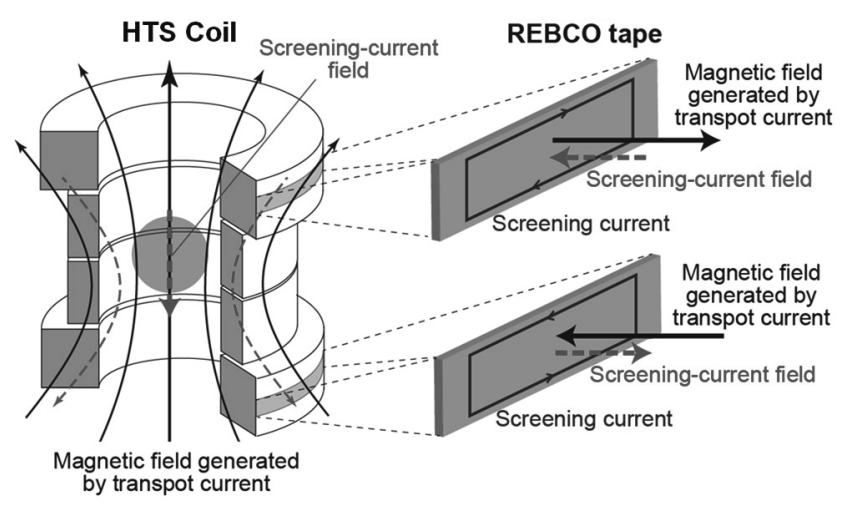

Fig. 5 Screening current-induced field.

$$
E=\frac{\rho_{F F}}{m+1}\left|J_{c m}\right|\left(\frac{\left|J_{c m}\right|}{J_{0}}\right)\left\{\left(1+\frac{J}{\left|J_{c m}\right|}\right)^{m+1}-1\right\}
$$

ここで, $m$ は臨界電流密度 $J_{c}$ 分布の形を与えるパラメータ, $J_{c m}$ は $J_{c}$ 分布の最小の臨界電流密度, $J_{0}$ は分布の半值幅を 与えるパラメータである。このモデルでは Fig. 4(b)のよう な $E-J$ 関係が得られる。すなわち, $T_{G L}$ 以下では, $J>$ $J_{c m}$ で磁束が運動できる状態になるが，低電界側では $E-J$ 特 性の $n$ 值が大きくなり, $J=J_{c m}$ で磁束がピンに固定される 臨界状態に至る。さらに温度上昇に従い, $n$ 值は低下し,

$T_{G L}$ 以上では, 磁束はピンに固定されないため臨界状態は 存在しない。なお，文献 23)では磁束クリープを考慮した モデルについて述べられている。

パーコレーションモデルを利用した高温超電導応用機器 の数值解析の例を 2 つ紹介する。

T. Nakamura らは, 高温超電導誘導同期モータ（High Temperature Superconducting Induction/Synchronous Motor: HTS-ISM）を提案し，研究開発を進めている 24,25)。この モータは磁束フロー領域で誘導モータとして, 低電界領域 で同期モータとして動作する。したがって，その特性評価 のためには, 高温超電導線材の幅広い電界領域の電流一電 圧特性が必要となる。T. Nakamura らは, 電流一電圧特性 をパーコレーションモデルとして考慮した等価回路解析 コードを利用して特性評価を行っている ${ }^{26,27) 。 ~}$

N. Amemiya らは, REBCO 線材で巻線された重粒子線治 療用回転ガントリー用コサインシータマグネットの線材磁 化を数值解析で評価しているが，この際，高温超電導線材 の電流一電圧特性にパーコレーションモデルを用いてい る ${ }^{28)}$ 。励磁後の磁場のドリフトの際, 超電導線内の電磁現 象が電流一電圧特性に沿って, 低電界側にシフトしていく 様子を明らかにしている。このような現象は，幅広い電界 領域の電流一電圧特性を再現できるパーコレーションモデ ルによってこそ議論できる。

\section{3. 高温超電導マグネットの遮蔽電流磁場}

REBCO 超電導線材は機械強度が高く, よりコンパクト な伝導冷却・高磁場マグネットの実現の可能性があるた
め, High Field Magnet や NMR, 加速器への適用が試みられ ている。これら NMR/MRI 用超電導マグネットあるいは加 速器用マグネットでは, 発生磁場は空間的に高精度かつ時 間的に高安定な磁場分布が要求される。高精度磁場が要求 される高温超電導マグネットを実現する際の問題として, 遮蔽電流により誘導される磁場（以下，遮蔽電流磁場 (screening current-induced field) と称する) がある。 REBCO 超電導線材は高いアスペクト比（5〜10 mm 幅に対して，超 電導層の厚さは $0.5 \sim 2.0 \mu \mathrm{m}$ 程度）を持つテープ線材であ る。このようなテープ線を用いて超電導マグネットを巻い て励磁すると, Fig.5のようにコイル径方向の磁場がテープ 面に垂直にかかり，線材中に遮蔽電流が誘導される。この 遮蔽電流が永久電流のように非常に長い時定数を持って テープ線内を周回するため, テープ線が磁化され, 不整磁 場（遮蔽電流磁場）が発生する。この遮蔽電流磁場は，コ イル中心磁場の低下, 磁場の空間均一性や時間的安定性の 低下を引き起こすことになる ${ }^{29)}$

\section{1 高精度磁場・高安定磁場}

数值解析を利用して, 実際の応用を想定した高精度磁場 や高安定磁場の評価がなされている。N. Amemiya らは, REBCO 線材で巻線されたコサインシータ・ダイポールマ グネットを対象に, 遮蔽電流による付加的な多極磁場成分 を数值解析によって計算している ${ }^{28)}$ 。K. Nakazono らは, MRI マグネットの磁場均一度に与える遮蔽電流磁場の影響 を数值解析によって評価した ${ }^{30)}$ 。

\section{2 マルチフィラメント化（細線化）}

E. Pardo らは，マルチフィラメントREBCO 線材の線材内 電流分布を計算している ${ }^{31)}$ 。H. Ueda らは，銅メッキで被 覆されたマルチフィラメント REBCO 線材で巻線されたコ イルを対象に, フィラメント間の抵抗と緩和特性の関係を 報告している ${ }^{32,33)}$ 。N. Amemiya らは, 銅メッキで被覆され たマルチフィラメント REBCO 線材で巻線されたコイルを 対象にフィラメント間の結合電流の減衰特性について数值 解析を行っている ${ }^{34)}$ 。

\section{3 簡易計算法}

これまでに開発されてきた超電導の電磁場解析手法は, 超電導特有の数理モデルや解析パラメータの設定が複雑で ある上, 計算容量・計算時間は膨大であり, 数值解析を利 用する者には大変な負担となり, 利用者が増えているとは 言えない状況である。そこで, 簡易的な遮蔽電流磁場の計 算法が提案されている。

（1）磁気モーメントループ K. Kajikawa らは, 遮蔽電 流がつくる磁気モーメントから磁場を計算する方法を提案 している ${ }^{35)}$ 。点 $(r, \varphi, z)$ に置かれた単位長さ当たり $m_{r}$ の径 方向磁気モーメントループが原点に作る軸方向磁場（遮蔽 電流磁場） $B_{S C F}$ は次式で表される。

$$
B_{S C F}=\frac{3 \mu_{0} m_{r} r^{2} z}{2\left(r^{2}+z^{2}\right)^{5 / 2}}
$$




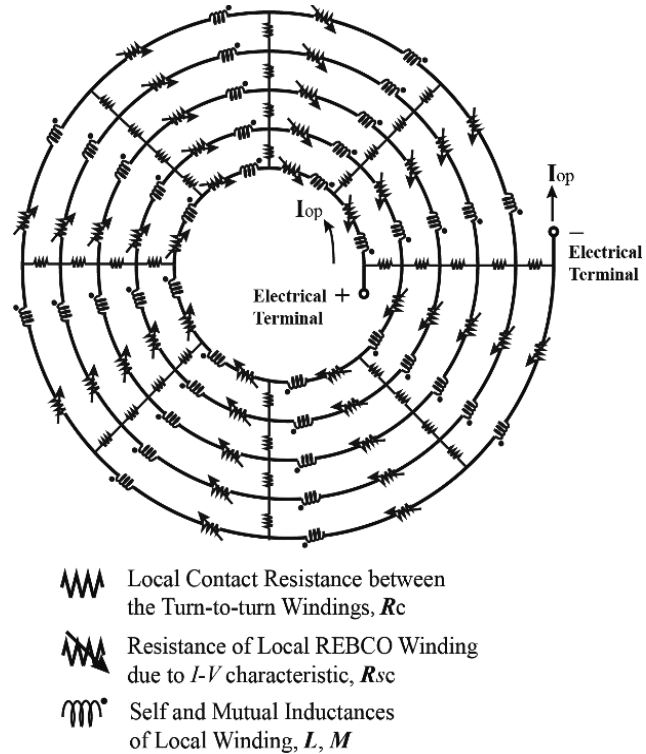

Fig. 6 Partial Element Equivalent Circuit (PEEC) model.

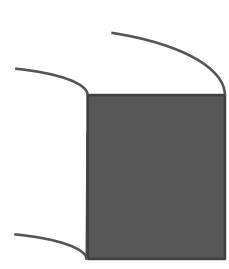

(a) Solid

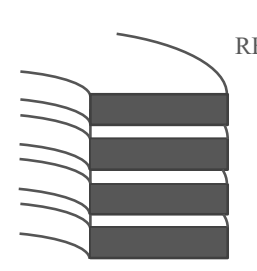

(b) Pancake

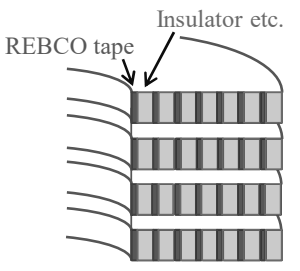

(c) Layer
Fig. 7 Cross-sectional model of HTS magnet design.

巻線の磁気モーメント $m_{r}$ が計算できれば，遮蔽電流磁場 $B_{S C F}$ が計算できる。ここで, K. Kajikawa らは，シングルパ ンケーキ全体をテープ幅の超電導無限平板で近似し，Bean モデルを仮定して, 磁気モーメント $m_{r}$ の表式を求めている 34)。この計算では，平板近似をしているため端効果の無視 により最内層と最外層に位置する数ターン分からの寄与を 小さく見積ることになることに注意しなければならない。 その結果，全体として若干過小評価することになる。

（2）遮蔽電流による磁場の理論的評価 Y. Mawatari ら は，ソレノイド状超電導コイルにおける電流・磁場分布に ついて理論解析を行い，テープ線材に流れる電流の不均一 性により生じる局所的な磁化と遮蔽電流磁場の関係を示す 簡潔な表式を導いている ${ }^{36,37) 。 ~}$

（3）等価回路計算法 S. Noguchi らは高度なシミュレー ション技術を要せずに，簡易的に REBCO コイル内に誘起 される遮蔽電流およびそれがつくる不整磁場を見積もる手 法を提案している ${ }^{38)}$ 。この計算法では，遮蔽電流に関する インダクタンスと REBCO テープ面に鎖交する平均磁場か ら容易に遮蔽電流を算出できる。有限要素法ほどの計算精 度は期待できないが, 設計時などに必要な計算精度は十分 に期待できる。また，後述の無絶縁コイルの等価回路計算 法との併用も可能である。なお，S. Noguchi は上記の計算 法に基づく REBCO パンケーキコイルの遮蔽電流磁場計算 ウェブサイト（https://hbd.ist.hokudai.ac.jp/scifweb/）を公開 している ${ }^{39)}$

\section{4. 無絶縁高温超電導マグネット}

無絶縁巻線技術（No-insulation winding technique; NI） 40) は, HTS コイルに局所的な特性劣化部が存在しても, 電流 が劣化部を避けて隣接するターンに迂回し，その通電特性 と電磁特性は劣化のないコイルとほぼ変わらなくなること が報告されている ${ }^{41)}$ このように，NI 技術は HTS コイル に高熱的安定性をもたらすため, 多くの高磁場発生用マグ ネットに採用され始めている。NI コイル特有の電磁的・熱 的振舞いを明らかにするための数值解析も行われており, 集中定数回路モデルや部分要素回路 (PEEC) モデル（Fig. 6) に基づく電流分布解析と有限要素法に基づく熱解析の 連成解析法が報告されている ${ }^{42,43)}$ 。

\section{5. 高温超電導マグネットの設計最適化}

MRI 用マグネットの設計においては，これまで，パン ケーキをスタックした構造の超電導マグネットに対して,

Fig. 7(a)(b)のように電流が巻線断面内を均一に流れている と仮定し, 磁場均一度を評価してきた。しかし, REBCO 線材の場合，パンケーキ間のギャップや基板などを考慮す ると, 電流が流れている部分は限定的であり, 空間的に離 散的に存在する。NMR や MRI, 加速器のような高精度磁 場, 高安定磁場が求められる応用においては，電流が流れ ている超電導層のみを考慮し, 磁場分布を評価する必要が ある。S. Noguchi らは, シングルパンケーキをスタックす る形態で最適化設計した形状で, Fig. 7(c)のように超電導層 に電流が集中している場合の MRI 用 REBCO コイルの磁場 均一度を評価した。上記従来法では, 精度よく均一度を評 価できず，Fig. 7(c)のようなモデルに基づく評価が必要であ ることを明らかにしている ${ }^{44-46) 。}$

\section{6. 最後に}

高温超電導応用機器の数值解析の現状について, 概説し た。高アスペクト比の高温超電導線材を用いた応用機器に おいて, その線材内の電磁現象を数值解析で精度よく計算 することはなかなか難しい。また, 超電導特性 $\left(I_{c} や E-J\right.$ 特性など）も特異な非線形性, 異方性があり, 人工ピンの 導入などで角度依存性が複雑になっている。これらの問題 は，汎用・商用ソフトで扱うことはできず，プログラムを 自作せざるを得ない状況であるため, 高温超電導体を含む 応用機器の数值解析は敷居が高くなりがちである。しか し, 本文に挙げた電磁簡易計算法の提案や商用ソフトも ユーザがカスタマイズして利用できるパッケージをリリー スし始めており，それらを利用した解析の報告も出てくる ようになってきた。今後, さらなる進展が期待される。 


\section{参 考 文 献}

1) H. Ueda and A. Ishiyama: "Numerical electromagnetic analysis for applied superconductivity I - Basics of numerical electromagnetic analysis -", TEION KOGAKU 47 (2012) 623-632 (in Japanese) 植田浩史, 石山敦士 : 「応用電磁気学 : 超電導機器応用のた めの電磁界数值解析 I - 電磁界数值解析の基礎 一」, 低温 工学 47 (2012) 623-632

2) H. Ueda and A. Ishiyama: "Numerical electromagnetic analysis for applied superconductivity II - Finite element method and boundary element method -", TEION KOGAKU 48 (2013) 83-94 (in Japanese)

植田浩史, 石山敦士 : 「応用電磁気学 : 超電導機器応用のた めの電磁界数值解析 II 一有限要素法と境界要素法一」, 低温 工学 48 (2013) 83-94

3) H. Ueda and A. Ishiyama: "Numerical electromagnetic analysis for applied superconductivity III - Superconductivity and electromagnetic analysis -", TEION KOGAKU 48 (2013) 472-484 (in Japanese)

植田浩史, 石山敦士 : 「応用電磁気学 : 超電導機器応用のた めの電磁界数值解析 III 一超電導特性と電磁界解析一」, 低 温工学 48 (2013) 472-484

4) http://www.sei.co.jp/super/hts/type_h.html

5) http://www.superpower-inc.com/content/2g-hts-wire

6) N. Amemiya and K. Akachi: "Magnetic field generated by shielding current in high Tc superconducting coils for NMR magnets", Supercond. Sci. Technol. 21 (2008) 095001.

7) N. Amemiya, T. Sano, T. Nakamura, T. Ogitsu, K. Koyanagi, T. Kurusu and H. Otake: "Temporal behaviour of multipole components of the magnetic field in a small dipole magnet wound with coated conductors", Supercond. Sci. Technol. 28 (2015) 035003

8) H. Ueda, M. Fukuda, K. Hatanaka, T. Wang, A. Ishiyama and S. Noguchi: "Spatial and temporal behavior of magnetic field distribution due to shielding current in HTS coil for cyclotron application”, IEEE Trans. Appl. Supercond. 23 (2013) 4100805

9) H. Zhang, M. Zhang and W. Yuan: "An efficient 3D finite element method model based on the T-A formulation for superconducting coated conductors", Supercond. Sci. Technol. 30 (2017) 024005

10) R. Brambilla, F. Grilli, L. Martini, M. Bocchi and G. Angeli: "A finite-element method framework for modeling rotating machines with superconducting windings", IEEE Trans. Appl. Supercond. 28 (2013) 5207511

11) K. Kajikawa and K. Funaki: "A simple method to eliminate shielding currents for magnetization perpendicular to superconducting tapes wound into coils," Supercond. Sci. Technol. 24 (2011) 125005

12) K. Kajikawa and K. Funaki: "Reduction of magnetization in windings composed of HTS tapes," IEEE Trans. Appl. Supercond. 22 (2012) 4400404

13) S. Noguchi and V. Cingoski: "Simulation of screening current reduction effect in REBCO coils by external AC magnetic field", IEEE Trans. Appl. Supercond. 27 (2017) 4701405

14) H. Ueda, Y. Imaichi, T. Wang, A. Ishiyama, S. Noguchi, S. Iwai, H. Miyazaki, T. Tosaka, S. Nomura, T. Kurusu, S. Urayama and H. Fukuyama: "Numerical simulation on magnetic field generated by screening current in 10-T-class REBCO coil”, IEEE Trans. Appl. Supercond. 26 (2016) 4701205

15) N. Tominaga, et al.: "Application of hierarchical matrices to largescale electromagnetic field analyses of coils wound with coated conductors", IEEE Trans. Appl. Supercond. 28 (2018) 4900305

16) Y. Sogabe and N. Amemiya: "Loss calculation of a cosine-theta dipole magnet wound with coated conductors by 3D modeling," IEEE Trans. Appl. Supercond. 28 (2018) 8200705

17) Y. Sogabe, T. Tsukamoto, T. Mifune, T. Nakamura and N. Amemiya: "Efficient and practical models for numerical electromagnetic field analyses of three-dimensional-shape coils wound with coated conductor", IEEE Trans. Appl. Supercond. 25 (2015) 4900205

18) E. Pardo: "Modeling of screening currents in coated conductor magnets containing up to 40000 turns", Supercond. Sci. Technol. 29 (2016) 085004

19) E. Pardo, J. Šouc and L. Frolek: "Electromagnetic modelling of superconductors with a smooth current-voltage relation: variational principle and coils from a few turns to large magnets", Supercond. Sci. Technol. 28 (2015) 044003

20) S. Awaji, K. Kajikawa, K. Watanabe, H. Oguro, T. Mitose, S. Fujita, M. Daibo, Y. Iijima, H. Miyazaki, M. Takahashi and S. Ioka: "AC losses of an HTS insert in a 25-T cryogen-free superconducting magnet”, IEEE Trans. Appl. Supercond. 25 (2015) 4601405

21) T. Matsushita, T. Tohdoh and N. Ihara: "Effects of inhomogeneous flux pinning strength and flux flow on scaling of current-voltage characteristics in high-temperature superconductors", Physica C 259 (1996) 321-325

22) K. Yamafuji and T. Kiss: "Current-voltage characteristics near the glass-liquid transition in high-Tc superconductors”, Physica C 290 (1997) 9-22

23) Y. Onodera, T. Kiss,, S. Gangi, K. Imamura, K. Higashikawa, M. Inoue, M. Yoshizumi and T. Izumi: "Critical current density in $\mathrm{Gd}_{1} \mathrm{Ba}_{2} \mathrm{Cu}_{3} \mathrm{O}_{7-\mathrm{i}}$ coated conductor under the influence of flux creep", Proceedings of the 25th International Cryogenic Engineering Conference and International Cryogenic Materials Conference 2014, Physics Procedia 67 (2015) 926-930

24) G. Morita, T. Nakamura and I. Muta: "Theoretical analysis of a YBCO squirrel-cage type induction motor based on an equivalent circuit", Supercond. Sci. Technol. 19 (2006) 473-478.

25) T. Nakamura, Y. Itoh, M. Yoshikawa, T. Nishimura, T. Ogasa, N. Amemiya, Y. Ohashi, S. Fukui and Mi. Furuse: "Tremendous enhancement of torque density in HTS induction/synchronous machine for transportation equipments", IEEE Trans. Appl. Supercond. 28 (2015) 5202304

26) H. Shimura, T. Nakamura, H. Kitano, T. Nishimura, N. Amemiya and Y. Itoh: "Calculated characteristics of HTS induction / synchronous machine below and above its critical temperature", IEEE Trans. Appl. Supercond. 23 (2013) 5201705

27) T. Nakamura, H. Shimura and N. Amemiya: "Analytical study on the operating temperature characteristics of high-temperature superconducting induction/synchronous motors", TEION KOGAKU 51 (2016) 174-184 (in Japanese) 中村武恒, 志村拡俊, 雨宮尚之：「高温超電導誘導同期モー夕 の駆動温度特性に関する解析的検討」, 低温工学 51 (2016) 178-184

28) N. Amemiya, Y. Sogabe, M. Sakashita, Y. Iwata, K. Noda, T. Ogitsu, Y. Ishii and T. Kurusu: "Magnetisation and field quality of a cosine- 
theta dipole magnet wound with coated conductors for rotating gantry for hadron cancer therapy", Supercond. Sci. Technol. 29 (2016) 024006

29) Y. Yanagisawa and H. Maeda: "Mechanism and suppressive methods for screening current-induced magnetic field of REBCO coils", TEION KOGAKU 48 (2013) 165-171 (in Japanese) 柳澤吉紀，前田秀明：「REBCO コイルにおける遮蔽電流磁場 のメカニズムと抑制方法」, 低温工学 48 (2013) 165-171

30) K. Nakazono, H. Ueda, A. Ishiyama A, S. Noguchi, H. Miyazaki, T. Tosaka, T. Kurusu, S. Nomura, S. Urayama and H. Fukuyama: "Numerical evaluation on irregular field generated by screening current in high-field REBCO coil for whole-body MRI", IEEE Trans. Appl. Supercond. 27 (2017) 4400405

31) E. Pardo, M. Kapolka, J. Kováč, J. Šouc, F. Grilli and R.N.A. Piqué: "Three-dimensional modeling and measurement of coupling AC loss in soldered tapes and striated coated conductors", IEEE Trans. Appl. Supercond. 26 (2016) 4700607

32）植田浩史，武藤優真，小曽根裕一，石山敦士：「銅メッキ付 き多芯REBCO テープ線材における遮蔽電流磁場の低減効果」, 電気学会金属・セラミックス／超電導機器合同研究会資料 (2017) MC-17-014, ASC-17-031

33）植田浩史, 小泉智暉, 盛川瑛亮, 金 錫範：「マルチフィラ メント高温超電導線材で巻線された高温超電導コイルの結合 電流分布解析」, 電気学会金属・セラミックス/超電導機器 合同研究会資料 (2018) MC-18-009, ASC-18-009

34) N. Amemiya, N. Tominaga, R. Toyomoto, T. Nishimoto, Y. Sogabe, S. Yamano and H. Sakamoto: "Coupling time constants of striated and copper-plated coated conductors and the potential of striation to reduce shielding current-induced fields in pancake coils", Supercond. Sci. Technol. 31 (2018) 025007

35) K. Kajikawa, G. V. Gettliffe, Y. Chu, D. Miyagi, T. P. Lécrevisse, S. Hahn, J. Bascuñán and Y. Iwasa: "Designs and tests of shaking coils to reduce screening currents induced in HTS insert coils for NMR Magnet", IEEE Trans. Appl. Supercond. 25 (2015) 4300305

36) Y. Mawatatri and Y. Higashi: "Theoretical evaluation of the screening-current-induced magnetic field in superconducting coils with tape wires", Abstracts of CSSJ Conference 94 (2017) 132 馬渡康徳，東 陽一：「テープ線材を用いた超伝導コイルにお ける遮蔽電流磁場の理論的評価」, 第 94 回 2017 年春季低温 工学・超電導学会講演概要集 (2017) 132

37) Y. Mawatatri, Y. Higashi: "Scaling law for the screening-currentinduced magnetic field in solenoid coils with superconducting tape wires”, Abstracts of CSSJ Conference 95 (2017) 2

馬渡康徳，東 陽一：「超伝導テープ線材を用いたソレノイド コイルにおける遮蔽電流磁場のスケール則」, 第 95 回 2017 年 秋季低温工学・超電導学会講演概要集 (2017) 25

38) S. Noguchi, H. Ueda, S. Hahn, A. Ishiyama and Y. Iwasa: "A simple screening current-induced magnetic field estimation method for REBCO pancake coils", Supercond. Sci. Technol. (2019) to be published.

39) S. Noguchi, T. Imai, D. Park, S. Hahn and Y. Iwasa: "Web page foe simulation of screening current-induced field for REBCO pancale coils”, Abstracts of CSSJ Conference 97 (2018) 94 野口 聡, 今井 適, D. Park, S. Hahn, 岩佐幸和 : $「 \mathrm{REBCO}$ パ ンケーキコイルの遮蔽電流磁場計算ウェブサイト」, 第 97 回 2018 年秋季低温工学・超電導学会講演概要集 (2018) 94
40) S. Hahn, et al.: "HTS pancake coils without turn-to-turn insulation", IEEE Trans. Appl. Supercond. 21 (2011) 1592-1595

41) S. Hahn, K. Radcliff, K. Kim, S. Kim, X. Hu, K. Kim, D. V. Abraimov and J. Jaroszynski: "Defect-irrelevant' behavior of a noinsulation pancake coil wound with REBCO tapes containing multiple defects", Supercond. Sci. Technol. 29 (2016) 105017

42) T. Wang, S. Noguchi, X. Wang, I. Arakawa, K. Minami, K. Monma, A. Ishiyama, S. Hahn and Y. Iwasa: "Analyses of transient behaviors of no-Insulation REBCO pancake coils during sudden discharging and overcurrent", IEEE Trans. Appl. Supercond. 25 (2015) 4603409

43) S. Noguchi, H. Ueda and A. Isihyama: "Numerical simulation techniques for no-insulation REBCO pancake coils - Comparison of models and simulation -", TEION KOGAKU 54 (2019) 103-110 (in Japanese)

野口 聡, 植田浩史, 石山敦士 : 「無絶縁 REBCO パンケー キ・コイルにおける数值解析技術一解析手法の比較および解 析事例一」，低温工学 54 (2019) 103-110

44) S. Noguchi, H. Miyazaki, T. Tosaka, S. Nomura, T. Kurusu, H. Ueda, A. Ishiyama, S. Urayama and H. Fukuyama: "Optimal configuration design of MRI REBCO magnet taking into account superconducting layer", 2016 IEEE Conference on Electromagnetic Field Computation (CEFC)

45) R. Miyao, H. Igarashi, SB. Kim and S. Noguchi, "Fast computation method of magnetic field homogeneity for NMR/MRI REBCO pancake coils", IEEE Trans. Appl. Supercond. 27 (2017) 4900204

46) A. Matsumi, H. Ueda, S. Noguchi, T. Wang, A. Ishiyama, H. Miyazaki, T. Tosaka, S. Nomura, T. Kurusu, S. Urayama and H. Fukuyama: "Evaluation of irregular magnetic field generated by screening current in REBCO coils for high accuracy field", IEEE Trans. Appl. Supercond. 26 (2017) 4702305

植田浩史 1977 年 2 月 3 日生。 2004 年 3 月早稲田大 学大学院理工学研究科電気工学専攻博士課程修了。2003 年 4 月 同大学理工学部助手, 2006 年 4 月同大学理工学術院総合研究所 客員講師 (専任扱), 2010 年 4 月（財）国際超電導産業技術研究 センター超電導工学研究所主任研究員, 2010 年 10 月大阪大学核 物理研究センター特任助教, 2016 年 3 月岡山大学大学院准教授, 現在に至る。主として超電導応用機器および電磁界数值解析に関 する研究に従事。低温工学・超電導学会, 日本加速器学会, 電気 学会会員, IEEE 会員。博士 (工学)。

野口聡 1972 年 1 月 19 日生。1994 年早稲田大学理工 学部電気工学科卒業。1 1999 年同大学院理工学研究科博士前期課程 (電気工学専攻) 修了。1999 年広島大学工学助手。2004 年より 北海道大学大学院情報科学研究科准教授。主に超伝導シミュレー ションに従事。低温工学・超電導学会, 電気学会, IEEE, ICS 会 員。博士 (工学)。

石山敦 士 1983 年 3 月早稲田大学大学院理工学研究科 電気工学専攻博士課程修了。1979 年 4 月同大学理工学部助手, 1991 年 4 月同教授, 現在に至る。主として超電導応用機器, 電 磁界数值解析法および生体磁気に関する研究に従事。低温工学・ 超電導学会, 電気学会会員。工学博士。 